\title{
Mansikan harmaahome: biologinen täsmähallinta haastaa kemiallisen torjunnan
}

Heikki Hokkanen $^{1)}$, Ingeborg Menzler-Hokkanen ${ }^{2)}$, Aino-Maija Mustalahti ${ }^{1)}$, Ilmo Koivisto ${ }^{3)}$, Markku Levy" ja Kari Korhonen ${ }^{4)}$

${ }^{1)}$ Helsingin yliopisto, Soveltavan biologian laitos, PL 27,00014 HY, heikki.hokkanen@ helsinki.fi

${ }^{2)}$ Helsingin yliopisto, Farmaseuttisen kemian osasto, PL 56, 00014 HY, imenzler@mappi.helsinki.fi

${ }^{3)}$ Savon ammatti- ja aikuisopisto, Jalkalantie 160, 77600 Suonenjoki, ilmo.koivisto@ sakky.fi

4) Marjaosaamiskeskus, Jalkalantie 6, 77600 Suonenjoki, kari.korhonen@suonenjoki.fi

\section{Tiivistelmä}

Mansikan harmaahome aiheuttaa vuosittain merkittäviä sadonmenetyksiä ja kuluja viljelijöille: tavalliset 3-4 hometorjuntaa kasvukautta kohti maksavat yli $1000 € /$ ha. Homeen biologista hallintaa on tutkittu paljon, mutta kenttäkokeet ovat yleensä noudattaneet kemiallisen torjunnan kaavaa, eikä riittävää tehoa tavallisesti ole saavutettu. Niinpä biologisen torjunnan läpimurto harmaahomeen torjunnassa on antanut odottaa itseään.

Koska harmaahome iskee mansikkaan kukan kautta, on ruiskutustorjunta tehotonta: valtaosa ruiskutteesta ei osu kukkiin. Lisäksi ruiskutuksen jälkeen avautuvat kukat jäävät ilman suojaa. Näitten heikkouksien korjaamiseksi ryhdyimme kehittämään mehiläisten avulla tapahtuvaa jatkuvaa täsmätorjuntaa. Tutkimuksessa mehiläiset valjastettiin kuljettamaan karvoituksessaan biotorjuntamikrobeja, jotka mehiläisten vieraillessa mansikan kukissa tehokkaasti ja täsmällisesti levisivät kohteeseensa. Itiölastin mehiläiset saivat poistuessaan pesästä erityisen levitinlaitteen läpi. Biotorjuntaan käytettiin kotimaista Gliocladium catenulatum -valmistetta (Prestop Mix).

Tutkimukset tehtiin Sisä-Savossa sijaitsevilla mansikkatiloilla. Vuonna 2006 mukana oli kolme ja 2007 viisi mansikkatilaa. Kaikkiaan tutkimuksissa oli neljä eri käsittelyä: (1) käsittelemätön verranne, (2) pelkkä kemiallinen torjunta, (3) pelkkä biologinen täsmätorjunta ja (4) sekä kemiallinen että biologinen torjunta. Mansikkapeltojen reunaan sijoitettiin kaksi vahvaa mehiläispesää/ha kukinnan alkaessa. Viljelijä lisäsi mikrobijauhetta levittimeen aamuisin noin 5-10 g kerrallaan. Sadepäivinä jauhetta levitettiin vasta sateen tauottua. Levitys lopetettiin kun mansikan kukinta oli ohi. Satokauden aikana kustakin käsittelystä tarkastettiin marjojen homeisuusaste 1-2 kertaa viikossa. Lisäksi v. 2007 tutkittiin mehiläisten vierailukäyntien tiheyttä mansikan kukissa, sekä selvitettiin eri käsittelyistä poimittujen marjojen kauppakestävyyseroja ns. rasiakokeilla. Kokeita tehtiin v. 2007 myös viidellä vadelmatilalla.

Molempina tutkimusvuosina tulokset kaikilta tiloilta olivat aivan samansuuntaiset. Alku- ja pääsatokauden aikana sekä biologinen että kemiallinen torjunta vähensivät marjojen homeisuutta noin puoleen tai alle siitä, mitä se oli ilman torjuntaa. Kemiallisen ja biologisen torjunnan yhteiskäyttö vähensi homeisuutta eniten, noin kolmannekseen. Kuivana kesänä 2006 tilanne säilyi samana satokauden loppuun, mutta vaikeana homekesänä 2007 ainoastaan yhteiskäyttö tehosi vielä satokauden lopussa. Vadelmalla tulokset olivat samansuntaiset, ja rasiakokeetkin vahvistivat niitä.

Tulokset osoittavat, että harmaahomeen täsmähallinta mehiläisten avulla on erittäin tehokas ja kilpailukykyinen, luomutuotantoonkin sopiva menetelmä. Biohallinta säästää paitsi ympäristöä, myös viljelijän työtä, kalustoa ja kustannuksia: hinta on vain noin kolmannes kemiallisen torjunnan kustannuksista. Yhteiskäytön optimoinnilla saatetaan tavanomaisilla tiloilla päästä parhaaseen taloudelliseen tulokseen.

\section{Asiasanat}

biologinen torjunta, Botrytis cinerea, Gliocladium catenulatum, harmaahome, integroitu torjunta, kemiallinen torjunta, luomutuotanto, mansikka, mehiläistarhaus, mesikasvit, pölytyspalvelu, siitepölykasvit, vadelma, ympäristö 


\section{Johdanto}

Harmaahome Botrytis cinerea aiheuttaa vuosittain suuria satotappioita mansikalla. Kattavasta kemiallisesta torjunnasta huolimatta sadonmenetys voi olla yli puolet sadosta; luomutuotannossa pahimmillaan $100 \%$. Homeentorjunta on myös kallista: rutiininomaiset 3-4 hometorjuntaa kasvukautta kohti maksavat tavallisesti yli $1000 € /$ ha. Vadelmalla ongelma on kasvuston ilmavuuden takia vähäisempi, mutta vaatii silti yleensä vuosittaisia torjuntakäsittelyjä.

Harmaahomeen biologista hallintaa on tutkittu paljon, ja lupaavia homeen antagonistimikrobeja on eristetty monia eri lajeja (Sutton, 1995). Torjuntakokeet biopreparaateilla ovat yleensä noudattaneet kemiallisen torjunnan kaavaa, eikä torjuntaruiskutuksilla tavallisesti ole saavutettu riittävää tehoa (esim. Prokkola ym., 2003). Niinpä biologisen torjunnan läpimurto harmaahomeen torjunnassa on antanut odottaa itseään.

Koska harmaahomeen ensisijainen infektio mansikkaan tapahtuu kukan kautta, ei ruiskuttamalla toteutettu torjunta voi olla kovin tehokasta: valtaosa ruiskutettavasta materiaalista osuu muualle kuin kukkiin. Lisäksi mansikan kukat, jotka avautuvat vasta ruiskutuksen jälkeen, jäävät ilman suojaa. Näitten heikkouksien korjaamiseksi on ryhdytty kehittämään mehiläisten avulla tapahtuvaa jatkuvaa täsmätorjuntaa. Ensimmäiset julkaisut aiheesta ovat jo 15 vuoden takaa (Peng ym., 1992), mutta menetelmää ei liene missään vielä viety tutkimuksellisia kenttäkokeita pitemmälle (esim. Yu ja Sutton, 1997, Kovach ym., 2000, Shafir ym., 2006).

Mehiläiset vierailevat mansikan kukissa ensisijaisesti keräämässä siitepölyä, varmistaen näin tehokkaan pölytyksen. Ne eivät kuitenkaan kuljeta karvoituksessaan ainoastaan siitepölyä, vaan voivat olla myös monien pieneliöitten passiivinen levittäjä. Jos varmistetaan, että mehiläiset kuljettavat kasvinsuojelullisesti hyödyllisiä pieneliöitä, voidaan ne erinomaisesti valjastaa biologisen torjunnan palvelukseen täsmälevittämään haluttuja eliöitä viljelykasvien kukkiin. Tutkimuksissa mehiläisiä ja eräitä muitakin pölyttäjähyönteisiä on käytetty levittämään biotorjuntamikrobeja kasvitautien ja tuhohyönteisten torjumiseksi mm. mansikalla, omenalla, päärynällä, pensasmustikalla, auringonkukalla, mailasella ja rapsilla (mm. Peng ym. 1992, Gross ym. 1994,Vanneste 1996, Jyoti ja Brewer 1999, Carreck ym. 2000).

Tämän tutkimuksen tarkoituksena oli selvittää, kuinka mehiläislevitteinen harmaahomeen biologinen hallinta saataisiin käytännössä toimimaan Suomen oloissa mansikalla ja vadelmalla, ja miten biologinen homeenhallinta toimii verrattuna tavanomaiseen kemialliseen homeentorjuntaan. Koska tutkimustietoa ei ole olemassa siitä, miten ahkerasti mehiläiset vierailevat mansikan kukissa ja millainen vaikutus vierailuaktiivisuuteen on muulla, kilpailevalla kukkakasvustolla, selvitettiin myös tätä. Lisäksi ensimmäisenä tutkimusvuotena saatiin viitteitä siitä, että biosuojatun mansikan kauppakestävyys saattaisi olla totuttua parempi. Siksi tutkimukseen lisättiin v. 2007 myös selvitys poimitun mansikan homehtumisalttiudesta säilytysrasiassa.

\section{Aineisto ja menetelmät}

Tutkimukset tehtiin Sisä-Savon alueella sijaitsevilla mansikkatiloilla. Vuonna 2006 mukana oli kolme ja vuonna 2007 viisi mansikkatilaa. Kaikkiaan tutkimuksessa oli neljä eri käsittelyä: (1) käsittelemätön verranne, (2) pelkkä kemiallinen torjunta, (3) pelkkä biologinen täsmätorjunta ja (4) sekä kemiallinen että biologinen torjunta. Kaikilla tiloilla ei käytännön syistä voitu toteuttaa kaikkia käsittelyjä, mm. koska mukana oli kaksi luomutilaa. Kaikilla tiloilla tutkimus tehtiin yleisellä, mutta homeelle alttiilla lajikkeella 'Polka'. Käsittelemätön verranne saatiin sijoittamalla mansikkakasvustoon kevyitä suojahäkkejä (noin $2 \mathrm{~m}$ x $3 \mathrm{~m}$ ), jotka estivät mehiläisten pääsyn näille koealoille. Mahdollista "häkkivaikutusta" homeen esiintymiseen ja siitä mahdollisesti syntyvää tulosten vääristymää tutkittiin kesällä 2007 yhdellä tilalla (2 suojahäkkiä). Harmaahomeen esiintymisessä ei kuitenkaan ollut satokauden aikana merkitsevää eroa sen välillä, olivatko mansikat olleet kukintavaiheessa häkkien ulkopuolella vai niitten sisäpuolella (käsittelemättömät lohkot). Kukinnan jälkeen suojahäkit poistettiin. Kemialliset torjunnat suoritettiin tiloilla normaalisti; kumpanakin vuotena tehtiin kolme kemiallista homeentorjuntaruiskutusta.

Mansikkapeltojen reunaan sijoitettiin kaksi vahvaa mehiläispesää/ha kukinnan alkaessa. Pesien ulostuloaukkoon oli kiinnitetty levitinlaite $\left(V^{2} k_{0}{ }^{\circledR}\right.$, Aasatek Oy), jonka läpi mehiläiset joutuivat 
kulkemaan tullessaan pesästä ulos. Samalla ne saivat karvoitukseensa annoksen torjuntamikrobia. Sisälle pesään mehiläiset kulkivat eri reittiä, jotta mikrobijauhetta ei kulkeutuisi pesän sisälle. Viljelijä lisäsi jauhetta levittimiin aamuisin noin 5-10 g kerrallaan. Sadepäivinä jauhetta levitettiin vasta sateen tauottua. Levitys lopetettiin kun mansikan kukinta oli ohi. Kaikkiaan biotorjuntajauhetta levitettiin kukinnan aikana noin 300-500 g/ha.

Biotorjuntamikrobina käytettiin kotimaista Gliocladium catenulatum -valmistetta (Prestop Mix, Verdera Oy). Hyötymikrobi Gliocladium catenulatum loisii tautia aiheuttavaa sientä kasvattamalla omaa rihmastoaan taudinaiheuttajan päälle ja tunkeutumalla sen sisään. Sitä esiintyy luontaisesti kaikilla mansikkapelloilla, ja se on todettu täysin haitattomaksi ihmisille, mehiläisille, ja muulle luonnolle (mikrobi on listattu EU:n kasvinsuojeludirektiivin liitteeseen 1, jonne on vasta hyväksytty kaikkiaan 6 eri mikrobia) (EU-SANCO, 2004). Valmiste on Suomessa hyväksytty luomukäyttöön, mutta sitä ei ole vielä rekisteröity harmaahomeen torjuntaan marjakasveilla, joten mansikan homeentorjunnassa sen käyttö vaatii vielä erityisluvan.

Satokauden aikana kustakin käsittelystä tarkastettiin marjojen homeisuusaste 1-2 kertaa viikossa. Kustakin kästtelystä tarkastettiin satunnaisesti sata marjaa (läpimitta yli $1 \mathrm{~cm}$ ) viidestä eri kohtaa (yhteensä 500 marjaa/tarkastuskerta/käsittely; joskus käytännön syistä vähemmän). Ylimääräistä vaihtelua tuloksiin toi se, että tarkastuskertoja ei voitu ajoittaa sen mukaan, milloin tilalla poimittiin satoa; näin tuloksiin vaikutti se, oliko ennen tarkastusta marjat juuri poimittu, vai oliko poiminta vasta edessä.

Vastaavia kokeita tehtiin v. 2007 myös viidellä vadelmatilalla, joista kahdella tuotettiin luomuvadelmaa ja kolmella tavanomaista.

Vuonna 2007 tutkittiin myös mehiläisten vierailukäyntien tiheyttä mansikan kukissa. Tarkkailija valitsi 10-20 mansikan kukkaa kerrallaan ja kirjasi mehiläisten ja muitten pölyttäjien käynnit kukissa tarkkailujakson aikana. Yksi tarkkailujakso oli tavallisesti 30 minuuttia, mutta joskus 15 tai 20 minuuttia. Kaikkiaan tarkkailtiin kukinnan aikana 445 eri kukkaa yhteensä yli 11 tunnin ajan.

Käsittelyjen mahdollista vaikutusta mansikoitten alttiuteen homehtua myyntirasiassa (kauppakestävyyteen) selvitettiin poimimalla kustakin käsittelystä kypsiä, terveitä marjoja rasioihin. Rasioita säilytettiin pöydällä huoneenlämmössä, ja marjojen kuntoa ja homeisuutta tarkasteltiin muutaman päivän välein, kunnes kaikki marjat olivat homeessa. Kaikkiaan vertailusarjoja tehtiin mansikalla $30 \mathrm{kpl}$. Neljästätoista sarjasta laskettiin homeisuusaste, lopuista ainoastaan arvioitiin neljän eri käsittelyn paremmuusjärjestys.

\section{Tulokset ja tulosten tarkastelu}

Molempina tutkimusvuosina tulokset kaikilta tiloilta olivat aivan samansuuntaiset. Alku- ja pääsatokauden aikana sekä biologinen että kemiallinen torjunta vähensivät marjojen homeisuutta vähintään puoleen siitä, mitä se oli ilman torjuntaa (Kuva 1). Kemiallisen ja biologisen torjunnan yhteiskäyttö alensi homeisuutta tavallisesti eniten, noin kolmannekseen tai alle siitä, mitä se oli käsittelemättömässä verranteessa. Kuivana kesänä 2006 homeisuusasteet olivat alhaisia (paitsi yhdellä tilalla, misä kasvustoa sadetettiin). Kemiallinen ja biologinen homeenhallinta toimivat yhtä hyvin: merkitseviä eroja menetelmien välillä ei ollut. Vaikeasta kesäsäästä ja hometilanteesta huolimatta vuonna 2007 homeprosentit tiloilla olivat tarkastusajankohtina pääosin varsin alhaisia; osa tästä selittyy ahkeralla homeisten marjojen poispoiminnalla. Biologinen homeenhallinta toimi tuolloinkin lähes yhtä hyvin kuin kemiallinen torjunta, alentaen homeisuuden noin puoleen verranteesta satokauden alussa ja sen keskivaiheessa (Kuva 1 B). Satokauden lopussa kummankin teho aleni. Biologisen ja kemiallisen hallinnan yhteisvaikutus toimi parhaiten läpi koko satokauden - vielä loppuvaiheessa homeisuusaste oli vain kolmasosa käsittelemättömän kerranteen homeisuudesta Kuva 1 B). Merkittävää on, että luomumansikalla tulokset olivat aivan yhtä hyviä - ajoittain parempiakin - kuin tavanomaisesti tuotetulla mansikalla. Koska tähän mennessä luomumansikan suojelemiseksi harmaahomeelta ei ole ollut mitään toimivaa keinoa, tarjoaa mehiläislevitteinen biohallinta näitten tulosten perusteella kemiallisen hometorjunnan veroisen keinon marjojen suojelemiseksi. 


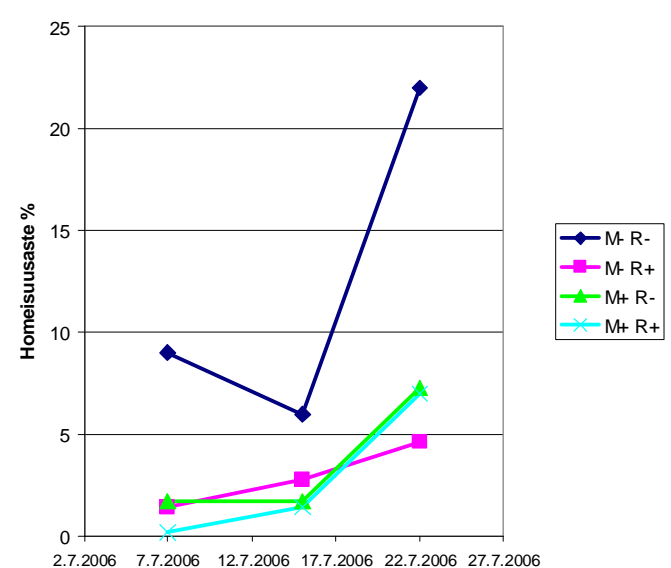

A

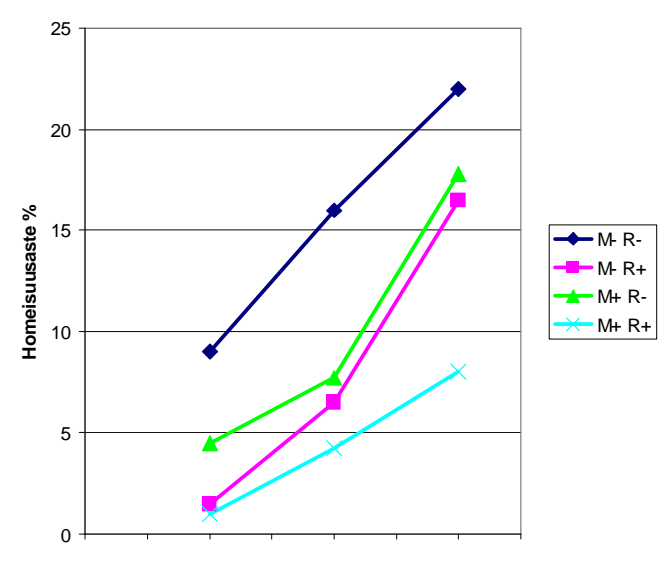

B

Kuva 1. Mansikan marjojen homeisuusaste satokauden alussa, puolivälissä ja lopussa kesällä 2006 (A) ja kesällä 2007 (B). Yhteenveto kolmen (2006) ja viiden (2007) tilan tuloksista. $(\mathrm{M}-\mathrm{R}-)=$ käsittelemätön kontrolli, $(\mathrm{M}-\mathrm{R}+)=$ pelkkä torjunta-aineruiskutus, $(\mathrm{M}+\mathrm{R}-)=$ pelkkä mehiläislevitteinen biotorjunta, $(\mathrm{M}+\mathrm{R}+)=$ sekä kemiallinen että mehiläislevitteinen biotorjunta.

Vadelmalla tulokset ovat hyvin samansuuntaisia (Kuva 2). Luomuvadelmalla biohallinta tuntui vaikuttavan jopa tehokkaammalta (Kuva $2 \mathrm{~A}$ ) kuin sama menetelmä tavanomaisella vadelmalla, missä jostain syystä satokauden alussa biohallinta ei ollut onnistunut (Kuva 2 B).
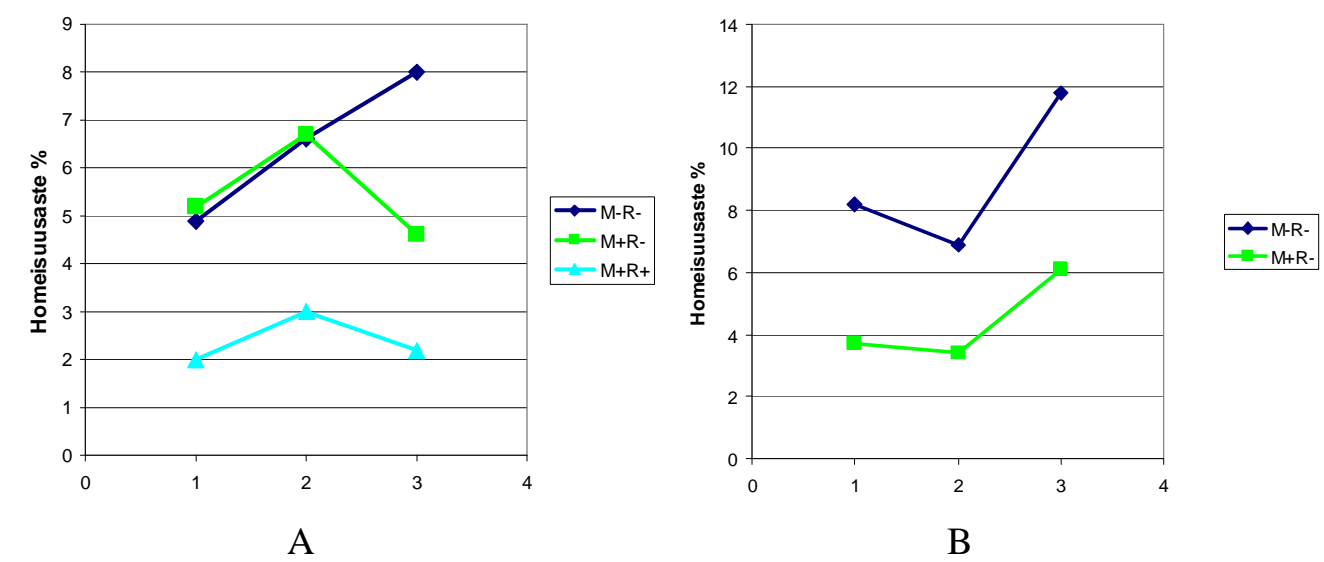

Kuva 2. Vadelman marjojen homeisuusaste satokauden alussa (1), puolivälissä (2) ja lopussa (3) kesällä 2007 tavanomaisilla tiloilla (A, kolme tilaa) ja luomutiloilla (B, kaksi tilaa). Merkinnät kuten kuvassa 1.

Harmaahomeen torjuntatapa aiheutti eroja myös marjojen kestävyyteen poiminnan jälkeen (Kuva 3). Säilytys huoneenlämmössä aiheutti nopean pilaantumisen: noin viikossa lähes kaikki marjat käsittelystä riippumatta olivat homeisia. Merkitseviä eroja saatiin kuitenkin noin 3-6 päivän säilytyksen jälkeen, jossa etenkin yhteiskäsittelyruuduilta poimitut mansikat olivat selvästi terveempiä (päivät 5 ja 6) kuin muut. Käsittelemättömästä verranteesta poimitut marjat pilaantuivat aina ensimmäisenä (Kuva 3). Koesarjoista, joissa käsittelyt ainoastaan laitettiin paremmuusjärjestykseen, olivat tulokset aivan samat. Erot käsittelyjen välillä saataisiin ehkä selvemmiksi, jos rasioita säilytettäisiin hieman huoneenlämpöä viileämmässä. 


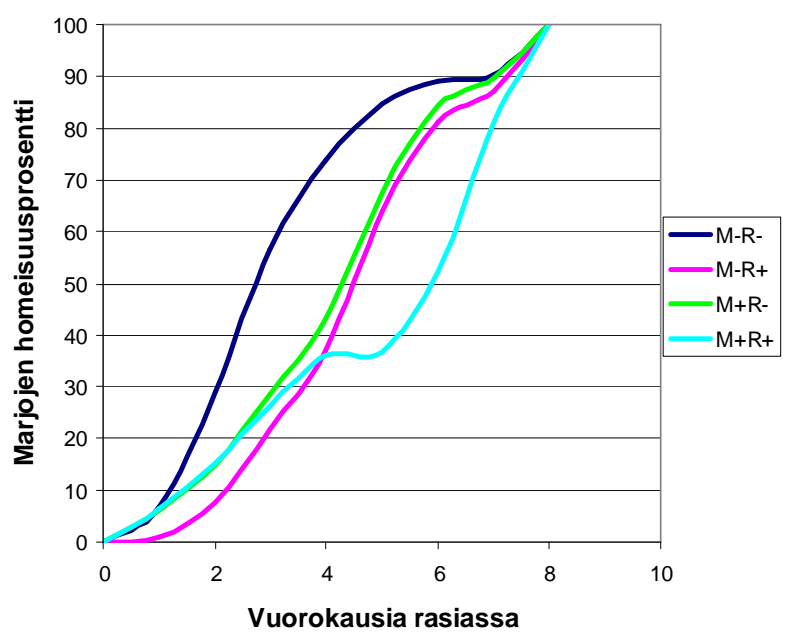

Kuva 3. Mansikan marjojen homeisuusasteen kehittyminen, kun niitä säilytettiin huoneenlämmössä avonaisissa myyntirasioissa. Marjat on poimittu neljästä eri käsittelystä; merkinnät kuten kuvassa 1. Seurantasarjoja oli kaikkiaan $14 \mathrm{kpl}$.

Ennakkokäsitys mansikasta mehiläiskasvina oli, että mikäli 'parempia' mesi- ja siitepölykasveja on lähistöllä, mehiläiset eivät juuri mansikassa vieraile. Kesän 2007 seurantatulokset kuitenkin yllättivät: mehiläiset kävivät ahkerasti mansikan kukissa läpi koko kukinta-ajan. Keskimäärin vierailuja kukkaa kohti tuli 1-2 kertaa tunnissa, eikä eroja juuri ollut kellonajan (tarkkailuja klo 9 ja 18 välisenä aikana) tai kukintakauden vaiheenkaan välillä. Mehiläiset vierailivat mansikan kukissa myös kun lämpötila oli vain +12 astetta. Kukissa käytiin myös huolimatta siitä, että lähistöllä oli mm. kukkivaa vadelmaa, apilaa, tai puolukkaa. Mikäli oletetaan, että lentosää suosii mehiläisiä, käyvät mehiläiset jokaisessa mansikan kukassa ainakin 10 kertaa päivässä silloin, kun mansikkahehtaaria kohti on käytössä kaksi vahvaa pesää.

Tämä vierailutiheys riittää hyvin biologisen hallinnan toteuttamiseksi: kyseessähän on ennen kaikkea 'kilpajuoksu' uuden resurssin (avautuva uusi mansikan kukka) valloittamiseksi. Harmaahomeen itiöitä lentelee ilmassa ja laskeutuu uuteen kukkaan sopivissa oloissa varsin pian. Kipailevan sienen, tässä tapauksessa luontaisesti esiintyvän Gliocladium catenulatum -sienen itiöitä saattaa myös joutua kukkaan, joko ennen harmaahometta tai sen jälkeen. Mehiläisten avulla pyritään varmistamaan, että hyötymikrobi ehtii kukkaan ennen homeitiöitä. Mehiläisten havaittiinkin nopeasti hakeutuvan etenkin uusiin, juuri avautuviin kukkiin.

Biologisessa torjunnassa on kyse paitsi 'kilpajuoksusta', myös tasapainosta haitallisten ja hyödyllisten eliöitten kesken. Mansikan kukan suojaamisen harmaahomeen iskeytymiseltä arvioidaan vaativan muutamia satoja Gliocladium-itiöitä. Pesästä lähtevä mehiläinen puolestaan kantaa karvoituksessaan noin 1000-10'000 itiötä, ja kukista, joissa tällaiset mehiläiset ovat muutaman kerran vierailleet, on mitattu keskimäärin 1000 itiötä/kukka (Peng ym., 1992). Näin mehiläislevityksellä voidaan nopeasti myös tuottaa biotorjunnalle edullinen tasapaino mansikan kukkiin, ja näin suojata kehittyvä mansikka.

\section{Johtopäätökset}

Tulokset osoittavat, että harmaahomeen täsmähallinta mehiläisten avulla on erittäin tehokas ja kilpailukykyinen, luomutuotantoonkin sopiva menetelmä. Biohallinta säästää paitsi ympäristöä, myös viljelijän työtä, aikaa, kalustoa ja kustannuksia: hinta on vain noin kolmannes kemiallisen torjunnan kustannuksista. Yhteiskäytön optimoinnilla saatetaan tavanomaisilla tiloilla päästä parhaaseen taloudelliseen tulokseen. 
Täsmätorjuntamenetelmää voidaan mahdollisesti käyttää myös monien muitten, tärkeitten kasvitautien ja tuholaisten torjuntaan. Meillä mahdollisia kohteita voisivat olla $\mathrm{mm}$. rypsillä pahkahomeen ja rapsikuoriaisen torjunta, sekä joittenkin tuholaisten ja tautien hallinta herukoilla, pensasmustikalla, vadelmalla, omenalla, jne (Kaipio ym., 2003). Menetelmä voi tarjota jatkossa mehiläistarhaajille mahdollisuuden yhdistää kaksi palvelutuotetta: pölytyspalveluun yhdistettynä voi ehkä myydä myös tauti- ja tuholaistorjuntapalveluja

\section{Kiitokset}

Kiitokset kaikille tutkimukseen osallistuneille viljelijöille loistavasta yhteistyöstä kokeitten toteuttamisessa, sekä innostuneesta asenteesta uusien menetelmien kehittämiseen. "Hunajainen MarjaSuomi" -hanke rahoitti osan tutkimuksesta. Kiitokset myös Verdera Oy:lle tuesta, yhteistyöstä ja neuvoista Prestop-valmisteen käytön suhteen.

\section{Kirjallisuus}

Carreck, N.L., Butt, T.M., Ibrahim, L., Pell, J.K. ja Williams, I.H. 2000. The use of honey bees to disseminate an insect pathogenic fungus for control of insect pests on oilseed rape. Apiacta 35: 25-28.

EU-SANCO 2004. Review report for the active substance Gliocladium catenulatum. Euroopan Komissio, raportti SANCO/10383/2004 - rev. 4.

Free, J.B. 1968. The foraging behaviour of honeybees (Apis mellifera) and bumblebees (Bombus spp.) on blackcurrant (Ribes nigrum), raspberry (Rubus idaeus) and strawberry (Fragaria x Ananassa) flowers. J. Appl. Ecol. 5: 157-168.

Gross, H.R., Hamm, J.J. ja Carpenter, J.E. 1994. Design and application of a hive-mounted device that uses honey bees (Hymenoptera: Apidae) to disseminate Heliothis nuclear polyhedrosis virus. Environmental Entomology 23: 492-501.

Jyoti, J.L. ja Brewer, G.L. 1999. Honey bees (Hymenoptera: Apidae) as vectors of Bacillus thuringiensis for control of banded sunflower moth (Lepidoptera: Tortricidae). Environmental Entomology 28: 1172-1176.

Kaipio, T., Menzler-Hokkanen, I., Pulakka, M. \& Hokkanen, H. 2003. Hunajamehiläisten (Apis mellifera) käyttäminen torjuntaeliöitten täsmälevittäjinä tuhohyönteisten ja kasvitautien biologisessa torjunnassa. Mehiläinen 20 (6): 176-179.

Kovach, J., Petzoldt R. ja Harman, G.E. 2000. Use of honey bees and bumble bees to disseminate Trichoderma harzianum 1295-22 to strawberries for Botrytis control. Biol. Contr. 18: 235-242.

Peng, G., Sutton, J.C. ja Kevan, P.G. 1992. Effectivness of honey bees for applying the biocontrol agent Gliocladium roseum to srawberry flowers to suppress Botrytis cinerea. Can. J. Plant Pathol. 14: 117-129.

Prokkola, S., Kivijärvi, P. ja Luoma, S. 2003. Luomumansikan harmaahomeelle etsittiin lääkkeitä. Koetoim. Käyt. 60(2): 11.

Shafir, S., Dag, A., Bilu, A., Abu-Toamy, M. ja Elad, Y. 2006. Honey bee dispersal of the biocontrol agent Trichoderma harzianum T39: effectiveness in suppressing Botrytis cinerea on strawberry under field conditions. Eur. J. Plant Pathol. 116:119-128.

Sutton, J.C. 1995. Evaluation of micro-organisms for biocontrol: Botrytis cinerea and strawberry, a case study. Adv. Plant Pathol. 11: 173-190.

Vanneste, J.L. 1996. Honey bees and epiphytic bacteria to control fire blight, a bacterial disease of apple and pear. Biocont. News Inform. 17(4): 67N-78N.

Yu H. ja Sutton J.C. 1997. Effectiveness of bumblebees and honeybees for delivering inoculum of Gliocladium roseum to raspberry flowers to control Botrytis cinerea. Biol. Contr. 10: 113-122. 